\title{
PERLINDUNGAN HUKUM TERHADAP KREDITUR ATAS DEBITUR ASING YANG DI NYATAKAN INSOLVENSI OLEH PUTUSAN PENGADILAN INDONESIA
}

\author{
Edwar Kelvin* \\ Law Office Edwar Kelvin \& Partners
}

\begin{abstract}
The fundamental reason for the Insolvency of Penaga Timur (M) SDN.BHD Shipping Companies from Malaysia is because they did not submit Peace Proposals at the Creditor Meeting as stipulated in Law Number 37 of 2004 concerning Bankruptcy and PKPU, and at that time the Bankruptcy Institution was no longer accepting The peace between the creditor and the debtor, as a result, the Curator appointed by the court must immediately issue all the assets of the bankrupt debtor, but is constrained by the location of the bankrupt debtor's assets outside the territory of the Republic of Indonesia, and of course this is very detrimental to PT. WAS and PT UML as Creditors as Justice Seekers. Researchers conducted descriptive-exploratory research with a juridical-normative approach.

From the results of the research that has been done, the researcher did not find a situation where the East Penol (M) SDN BHD insolvency was caused by the cash flow test approach method, or the balance sheet test or going concern value concept and also had no relation to the assessment of debtor financial ratios such as liquidity (liqidaty), solvency (solvability), profitability (profitability) and leverage as it applies in the Perspective of Bankruptcy Regime in general, and in this case the lack of regulation regarding the provisions of International Law relating to the Ordering of a Bankruptcy and / or Cross Border Insolvency in general. The curator has not been able to fulfill the rights of creditors for bankruptcy bodies outside the territory of the Republic of Indonesia.
\end{abstract}

Keywords: Cross Border Insolvensy, Bankruptcy Bankruptcy, Creditors, Foreign Debtors, Legal Protection.

\begin{abstract}
Abstrak
Alasan fundamental Insolvensinya Debitur Pailit Penaga Timur (M) SDN.BHD Perusahaan Pelayaran Asal Malaysia adalah dikarenakan tidak mengajukan Proposal Perdamaian pada saat Rapat Kreditur sebagaimana yang diatur dalam UU Nomor 37 Tahun 2004 tentang Kepailitan dan PKPU, dan saat itu pula Pranata Kepailitan tidak lagi menerima Perdamaian yang dilakukan antara Kreditur dan Debitur, akibatnya Kurator yang diangkat Pengadilan harus segera melakukan pemberesan terhadap seluruh harta Debitur pailit namun terkendala oleh karena letak Harta Debitur Pailit berada di Luar Wilayah Republik Indonesia, dan tentunya hal ini sangat merugikan PT. WAS dan PT UML sebagai Para Kreditur sebagai Para Pencari Keadilan.

Peneliti melakukan penelitian yang bersifat deskriptif-eksploratoris dengan metode pendekatan yuridis-normatif.

Dari hasil penelitian yang telah di lakukan, Peneliti tidak menemukan keadaan dimana Insolvensinya Penaga Timur (M) SDN BHD disebabkan oleh metode
\end{abstract}

*Alamat Korespondensi : kevingibi93@gmail.com 
pendekatan cash flow test, maupun balance sheet test atau konsep going concern value dan juga tidak memiliki kaitannya dengan penilaian rasio keuangan debitur seperti likuiditas (liqidaty), solvabilitas (solvability), profitabilitas (profitability) dan leverage seperti yang berlaku dalam Perspektif Rezim Kepailitan pada umumnya, dan dalam hal ini minimnya pengaturan tentang ketentuan - ketentuan Hukum Internasional yang berkaitan dengan Pemberesan Boedel Pailit dan/atau Cross Border Insolvensy menyebabkan Kurator belum dapat memenuhi hak - hak para Kreditur terhadap bodle pailit yang berada di luar Wilayah Republik Indonesia.

Kata Kunci : Cross Border Insolvensy, Boedel Pailit, Kreditur, Debitur Asing, Perlindungan Hukum.

\section{A. Latar Belakang Masalah.}

Esensi permasalahan dalam bisnis Internasional pada umumnya terkait permasalahan keperdataan Internasional yang salah salah satu nya adalah di bidang Kepailitan lintas negara dalam transaksi bisnis Internasional yang dikenal dengan istilah kepailitan lintas batas negara (cross - borrder insolveency);

Phiilip R. Wod menyatakan :

"cross - border insolvency is proceedings overrode the previos strict territorially of state insolvency proceedings which did not extend to assets located in doreign countries or vice versa"1.

Adapun Daniel Suryana menyatakan sebagai :

"Kepailitan yang timbul dari suatu transaksi bisnis Internasional, yang mana terdapat unsur asing (foreign elements) di dalamnya, namun bukan berasal dari negara dimana proses kepailitan tersebut dilakukan dinamakan kepailitan lintas batas negara (Cross-Border Insovency)". ${ }^{2}$

Berdasarkan kajian teoritis diatas, dapat di tarik kesimpulan bahwa kepailitan lintas batas adalah sebuah kasus yang melibatkan unsur Negara Asing di dalamnya baik dari kedudukan Kreditur ataupun Debitur. Pranata Kepailitan Antar Negara sejatinya hampir sama dengan kepailitan hanya saja dalam kepailitan antar negara harus memiliki organ - organ asing di dalamnya.

Dikutip dari pendapat Sunaryati Hartono menyatakan bahwa dalam perkara kepailitan terdapat kemungkinan memiliki aspek Internasional dikarenakan faktor - faktor sebagai berikut:

1. "Debitur Asing,atau

2. Kreditur Asing,atau

3. Benda dan/atau aset yang berada di luar negeri,atau

4. Benda atau aset perusahaan yang dimiliki oleh orang asing". 3

UU Nomor 37 Tahun 2004 tentang Kepailitan dan Penundaan Kewajiban Pembayaran Utang (selanjutnya disebut UU K-PKPU) yang saat ini diakui di Indonesia, tidak hanya mengakomodir persengketaan antara Para Pihak yang

\footnotetext{
${ }^{1}$ Philip R. Wood dalam Bayu Seto Hardjowahono, Dasar - Dasar Hukum Perdata Internasional Buku Kesatu, PT Citra Aditya Bakti, 2006,hlm.4.

2 Sudargo Gautama, Hukum Perdata Internasional Indonesia Buku Kesatu, PT Alumni, Bandung, 2008.

${ }^{3}$ Sunaryati Hartono, "Manfaat Ketentuan - Ketentuan Internasional dalam Penyelesaian Harta Pailit”, Makalah Seminar Sosialisasi Rancangan Undang - Undang Tentang Kepailitan, Badan Pembinaan Hukum Nasional - Departemen Kehakiman bekerja sama dengan elips Project,1999, hlm.1.
} 
berdomisili di Wilayah Republik Indonesia, melainkan juga berlaku terhadap Debitur yang berada di Luar Wilayah Indonesia hal ini secara tegas diatur dalam pasal 3 ayat (4) UU K-PKPU ${ }^{4}$.

Hadirnya Pasal 3 ayat (4) UU K-PKPU tersebut tentunya menjadi angin segar bagi para pencari keadilan berdarah Indonesia yang berurusan hukum terhadap perusahaan asing, namun apabila mencermati secara mendalam maka akan timbul polemik - polemik yang menjadi ladang perdebatan dalam dunia praktisi Hukum khususnya dalam pranata kepailitan, seperti tentang bagaimana penentuan pailitnya seseorang atau badan hukum tersebut sebab badan hukum (legal entity) dan organ - organnya berada di Luar Wilayah Indonesia yang mengikat terhadap Hukum Negaranya lantas bagaimana pula melakukan eksekusi terhadap Harta Benda tatkala menurut Hukum Indonesia Legal Entity Asing tersebut dinyatakan Pailit? tentunya hal ini menjadi buah bibir yang tidak pernah terpecahkan sampai dengan Peneliti mengangkat Tesis ini.

Contohnya saja nasib Para Kreditur PT. Wijaya Artha Shiping (PT.WAS) dan PT. Ujung Medini Lestari (PT.UML) yang menuntut utangnya sejumlah Rp. 12.991.106.500,- (dua belas milyar sembilan ratus Sembilan puluh satu juta seratus enam ribu lima ratus rupiah) terhadap Debitur Asing bernama PENAGA TIMUR (M) SDN BHD Perseroan asal Malaysia pada Pengadilan Niaga pada Pengadilan Negeri Medan sampai dengan saat ini belum dapat merasakan hak - haknya.

Hal ini lantaran PENAGA TIMUR (M) SDN BHD tidak bisa menerima Putusan Pengadilan Indonesia yang telah mempailitkan dirinya hanya karena tidak mengajukan Proposal Perdamaian terhadap Para Kreditur, padahal hal tersebut telah diatur dalam Pasal 178 UU K-PKPU yang menyatakan untuk menetapkan seseorang atau badan hukum dinyatakan pailit adalah salah satunya tidak mengajukan Perdamaian. Akibatnya antara Kreditur dan Debitur tidak lagi terbuka pintu Perdamaian sebab setelah Legal Entity tersebut dinyatakan insolvensi jalan satu - satunya hanyalah melakukan Pemberesan Harta Pailit yang di lakukan oleh Kurator. Tentunya secara tidak langsung, hakikat yang terkandung dalam Pasal 1858 KUHPerdata ${ }^{5}$ sebagai landasan Fundamental dalam Pranata Keperdataan telah tercederai oleh hadirnya Pasal 178 UU K-PKPU tersebut.

Namun suka tidak suka mau tidak mau Kurator yang di angkat Pengadilan di wajibkan untuk melakukan pemberesan terhadap harta - harta Debitur Pailit untuk di didaftarkan dalam daftar boedle pailit demi menutupi seluruh utang - utang milik Debitur PENAGA TIMUR (M) SDN BHD terhadap PT. WAS dan PT.UML selaku Para Kreditur akan tetapi teori tidaklah seindah praktiknya, Kurator yang diharapkan sebagai "juru Kunci" kreditur untuk mendapatkan hak - haknya malah mengalami kendala - kendala tatkala harta benda tersebut berada wilayah kedaulatan/yurisdiksi negara Debitur Asing yang bersangkutan, dalam hal ini berada di kedaulatan Negara Malaysia tempat dimana Debitur Asing PENAGA TIMUR (M) SDN BHD berada.

\section{B. Rumusan Masalah}

1. Bagaimanakah perspektif rezim hukum kepailitan dalam memandang Debitur Asing yang Insolvensi berdasarkan Undang - undang Nomor 37 Tahun 2004 tentang Kepailitan dan PKPU?

\footnotetext{
${ }^{4}$ Pasal 3 ayat 4 UU Nomor 37 Tahun 2004

${ }^{5}$ Pasal 1858 KUHPerdata
} 
2. Bagaimanakah peranan Kurator dalam memenuhi hak - hak Para Kreditur terhadap bodle pailit yang berada di Luar Wilayah Republik Indonesia?

3. Langkah - langkah apa saja yang dapat digunakan untuk memberi kepastian hukum bagi Para Kreditur atas bodle pailit yang berada di Luar Wilayah Republik Indonesia?

\section{Metode Penelitian.}

Metode pendekatan yang digunakan dalam penelitian ini adalah bersifat yuridis-normatif, yaitu suatu penelitian yang menitikberatkan pada penggunaan data sekunder di bidang hukum melalui studi literatur/ dokumen (penelitian kepustakaan).

Dalam penelitian ini peneliti menggunakan spesifikasi penelitian yang bersifat deskriptif-eksploratoris, yaitu dimaksudkan untuk memberi data seteliti mungkin tentang suatu keadaaan atau gejala-gejala lainnya sekaligus mencoba untuk melakukan suatu penjelajahan terhadap berbagai asas dan kaidah hukum kepailitan, hal mana peneliti mencoba untuk melakukan penjajakan terhadap perspektif rezim hukum kepailitan dalam memandang Debitur Asing yang Insolvensi berdasarkan Undang - undang Nomor 37 Tahun 2004 tentang Kepailitan dan Penundaan Kewajiban Pembayaran Utang yang mengakibatkan Kurator sangat berperan untuk memenuhi hak - hak Para Kreditur terhadap bodle pailit yang berada di Wilayah Republik Indonesia serta menjelaskan langkah kongkrit apa yang dapat digunakan untuk dapat memberikan kepastian hukum bagi Para Kreditur atas bodle pailit yang berada di Luar Wilayah Republik Indonesia.

Adapun spesifikasi penelitian yang bersifat eksploratif tadi didasari oleh suatu pertimbangan bahwa sejauh studi literatur yang telah dilakukan oleh peneliti belum didapatkan suatu penelitian yang khusus memfokuskan pada kedudukan bagi Para Kreditur atas bodle pailit yang berada di Luar Negeri sebab konsideren pembuatan UU K-PKPU salah satunya menyatakan UU K-PKPU merupakan Produk Nasional yang menjamin kepastian, ketertiban, penegakan dan perlindungan hukum yang berintikan keadilan dan kebenaran. Dengan demikian diharapkan agar penelitian ini dapat mencari sekaligus menemukan gagasan baru berupa landasan hukum yang tepat melalui pendalaman asas-asas dan kaidah hukum secara sinkron dan terpadu berkenaan dengan hukum kepailitan guna memberikan solusi efektif dalam rangka perlindungan hukum kepada kreditor sebagaimana dimaksud.

Jenis penelitian yang digunakan peneliti dalam melaksanakan penelitian ini adalah penelitian hukum secara normatif Penelitian hukum secara normatif atau penelitian hukum secara kepustakaan ${ }^{6}$ merupakan penelitian yang dilakukan dengan mengkaji peraturan perundang-undangan yang berlaku dan bahan-bahan pustaka lainnya yang lazimnya dinamakan data sekunder, untuk diterapkan terhadap suatu permasalahan hukum tertentu. ${ }^{7}$

Dalam penelitian ini, Peneliti menggunakan data sekunder dan data Primer dimana Data Primer tersebut bertujuan untuk melengkapi data sekunder Peneliti

\footnotetext{
${ }^{6}$ Pada penelitian hukum normative, bahan pustaka merupakan data dasar yang dalam (ilmu) penelitian digolongkan sebagai data sekunder. Soerjono Soekanto dan Sri Mamudji. Op. CIt., hlm. 23-24.

${ }^{7}$ Ibid. hlm. 14 .
} 
Dalam penelitian ini data diperoleh dari teknik pengumpulan data yang dilakukan dengan cara:

1. Studi Literatur/ Dokumen

yakni melakukan penelitian terhadap kepustakaan yang berkaitan dengan objek penelitian untuk mendapatkan landasan teoritis;

2. Wawancara

yakni mengadakan wawancara secara langsung dengan pihak-pihak yang terkait dengan objek penelitian, dalam hal ini peneliti lebih menitik beratkan dan berfokuskan untuk melakukan wawancara dengan kurator dan pengurus yang telah beberapa kali melaksanakan tugasnya dalam melakukan kegiatan pengurusan dan/ atau pemberesan terhadap harta pailit (boedel).

3. Participant Observation.

Peneliti yang notabennya selaku Kuasa Hukum Para Kreditur terlibat langsung dalam Putusan Perkara yang diteliti dalam penelitian ini.

Pada penelitian ini menggunakan metode analisis yuridis kualitatif. Pengelolaan data pada penelitian hukum normatif dengan analisis kualitatif ${ }^{8}$ adalah kegiatan untuk mengadakan sistematis terhadap bahan-bahan hukum tertulis. Sistematisasi berarti membuat klasifikasi terhadap bahan-bahan tertulis tersebut untuk memudahkan pekerjaan analis dan konstruksi.

\section{Hasil Penelitian dan Pembahasan}

1. Perspektif rezim hukum kepailitan dalam memandang Debitur Asing yang Insolvensi berdasarkan Undang - Undang Nomor 37 Tahun 2004 tentang Kepailitan dan Penundaan Kewajiban Pembayaran Utang

Pada dasarnya Pasal 1 KUH Perdata menegaskan bahwa menikmati hak-hak kewargaan tidak tergantung pada hak-hak kenegaraan, ini berarti hak - hak warga negara asing juga berhak menikmati hak-hak kewarganegaraan yang dinikmati oleh warga negara Indonesia begitu juga sebaliknya, tidak memandang mereka dari negara apapun. Berkaitan dengan hal tersebut maka dalam konsepsi keperdataan pada hakikatnya tidak memandang hubungan hukum yang dilakukan antar perorangan dari sudut pandang sebuah negara, artinya siapa saja dan dari mana saja, di Indonesia selalu terbuka pintu lebar untuk melaksanakan sebuah perikatan hukum termasuk pula dalam melakukan kegiatan bisnis. Hal ini dapat terlihat dari semakin berkembangnya arus bisnis dari suatu Negara ke Negara lain, kegiatan bisnis ini dapat terlihat dari banyak hal misalnya melalui ekspor impor, investasi, perdagangan jasa, lisensi, waralaba, joint venture, atau kegiatan bisnis lainnya. ${ }^{9}$

Perkembangan dalam kegiatan bisnis dari masa ke masa mengalami peningkatan yang sangat pesat. Tidak hanya di lingkup satu Negara saja melainkan sampai antar Negara dalam melakukan kegiatan bisnis. Hal ini terlihat dari semakin berkembangnya arus bisnis dari suatu Negara ke Negara lain, kegiatan bisnis ini dapat terlihat dari banyak hal misalnya melalui ekspor impor, investasi, perdagangan jasa, lisensi, waralaba, joint venture, atau kegiatan bisnis lainnya.

Namun dalam perjalananya, sangat rentan terjadinya perselisihan mana kala kegiatan bisnis yang dilakukan antar pengusaha lokal dan asing terjadi persisihan, tentunya pertanyaan mendasar timbul, bahwa hukum mana yang akan di pakai jika

\footnotetext{
${ }^{8}$ Mukti Fajar ND, Yulianto Achmad, Op. Cit., hlm. 183.

${ }^{9}$ Warren J Keegan, Global Marketing Management, Sevent Edition, (United State: Prentice Hall, 2002), Hlm 11
} 
terjadinya perselisihan antara Pengusaha Asing dengan Pengusaha Lokal. Contohnya yang terjadi pada tahun 1997 saat krisis moniter yang lalu, dimana banyak perusahaan asing kebingungan mencari solusi terbaik untuk menagih piutang mereka kepada Pengusaha Lokal Indonesia dan sebaliknya hal yang sama juga terjadi terhadap Pengusaha Lokal juga tidak luput dari kebingungan tersebut;

Esensi permasalahan dalam bisnis Internasional pada umumnya terkait permasalahan keperdataan Internasional yang salah salah satu nya adalah di bidang Kepailitan lintas negara dalam transaksi bisnis Internasional yang dikenal dengan istilah kepailitan lintas batas negara (cross - borrder insolveency);

Untuk melindungi seluruh warga Indonesia yang turut serta dalam melakukan kegiatan bisnis Lintas negara, Indonesia telah menghadirkan sebuah Kerangka Hukum yaitu UU KK-PKPU yang di undangkan pada tanggal 18 Oktober 2004, terdiri dari 6 (enam) bab yang berisi 308 pasal dan diantara bab - bab dan pasal pasal tersebut telah mengakomodir norma - norma yang mengatur tentang kepailitan lintas batas negara (cross - border insolvency) .

Perbedaan antara UU K-PKPU dengan Undang - undang dalam Pranata Keperdataan pada umumnya, salah satunya terletak pada pengaturan secara khusus tentang pengajuan Kepailitan terhadap kedudukan domisili sebuah Badan Hukum Asing, hal ini dapat kita lihat dalam pasal 3 ayat (4) UU K-PKPU yang menyebutkan:

"Dalam hal debitur tidak berkedudukan di wilayah negara Republik Indonesia tetapi menjalankan profesi atau usahanya di wilayah negara Republik Indonesia Pengadilan yang berwenang memutuskan adalah Pengadilan yang daerah hukumnya meliputi tempat kedudukan atau kantor pusat Debitor menjalankan profesi atau usahanya di wilayah negara Republik Indonesia”;

Artinya Badan Hukum Asing yang beroperasi di Wilayah Indonesia diwajibkan untuk tunduk dan taat terhadap seluruh aturan - aturan yang diatur dalam UU KPKPU tersebut yang salah satunya adalah berkaitan dengan penjatuhan Keadaan Insolvensi pada diri seseorang atau badan hukum Asing.

Berkaitan dengan penjatuhan Insolvensi, maka di dalam UU PKPU telah mengatur secara eksplisit sebagaimana yang dimaksud Pasal 178 ayat (1) UU KPKPU yang berbunyi:

"Jika dalam rapat pencocokan piutang tidak ditawarkan rencana perdamaian, rencana perdamaian yang ditawarkan tidak diterima, atau pengesahan perdamaian ditolak berdasarkan putusan yang telah memperoleh kekuatan hukum tetap demi hukum harta pailit berada dalam keadaan insolvensi". ${ }^{10}$

Menurut ketentuan diatas secara prosedural menurut ketentuan pasal ini keadaan- keadaan yang dimaksud adalah sebagai berikut :

"a. Dalam rapat verifikasi tidak ditawarkan perdamaian;

b. Perdamaian yang ditawarkan telah ditolak;

c. Pengesahan perdamaian tersebut dengan pasti telah ditolak.”

Di satu sisi, apabila mencermati UU K-PKPU maka Istilah dan Definisi dari Insolvensi secara nyata berbeda dengan hakikat yang terkandung dalam Pasal 178 Ayat (1) yang telah di jelaskan diatas, hal ini dapat dilihat dari Penjelaskan Pasal 57 ayat (1) UU Kepailitan dan PKPU, yang berbunyi:

"Yang dimaksud dengan Insolvensi adalah keadaan tidak mampu membayar"

Menurut Peneliti, terdapat sebuah perbedaan yang mendasar yang di perlihatkan oleh UU K-PKPU tersebut, disatu sisi menyebutkan Insolvensi adalah keadaan

${ }^{10}$ Insolvensi adalah keadaan tidak mampu membayar (Penjelasan Pasal 57 ayat 1 UU K-PKPU) 
dimana debitur tidak mampu membayar, namun disisi lain Insolvensi dapat di jatuhkan apabila debitor tidak mengajukan rencana perdamaian pad asaat rapat verivikasi yang dilakukan oleh kurator.

Penjatuhan keadaan Insolvensi sebagaimana yang diatur dalam Pasal 178 ayat (1) UU K-PKPU tersebut secara nyata ditemukan dalam Perkara antara PT. Wijaya Artha Shiping (PT.WAS) dan PT. Ujung Medini Lestari (PT.UML) selaku Kreditur yang mengajukan Permohonan Penundaan Kewajiban Pembayaran Utang (PKPU) sejumlah Rp. 12.991.106.500,- (dua belas milyar sembilan ratus Sembilan puluh satu juta seratus enam ribu lima ratus rupiah) terhadap Debitur Asing bernama PENAGA TIMUR (M) SDN BHD Perseroan asal Malaysia pada Pengadilan Niaga pada Pengadilan Negeri Medan, dimana Pengadilan Medan telah menjatuhkan Putusan PKPU Sementara selama 45 (empat puluh lima) hari sebagaimana yang di maksud dalam Putusan Nomor 11/Pdt.Sus-PKPU/2018/PN.Niaga Mdn.

Namun dalam kurun waktu PKPU selama 45 (empat puluh lima ) hari yang di tentukan, PENAGA TIMUR (M) SDN BHD selaku Debitur tidak kunjung menawarkan Rencana Perdamaian terhadap Para Kreditur sebagaimana diamanatkan dalam ketentuan UU K-PKPU, maka bersandarkan Pasal 178 Ayat (1) UU K-PKPU Majelis Hakim Pengadilan Niaga Medan telah menjatuhkan Pailit terhadap PENAGA TIMUR (M) SDN BHD. Seketika itu pula pintu perdamaian antara Debitur dan Para Kreditur telah tertutup walaupun kedepannya Debitur PENAGA TIMUR (M) SDN BHD merasa mampu untuk membayar seluruh utang - utang nya kepada Para Kreditur. Tentunya secara tidak langsung, hakikat yang terkandung dalam Pasal 1858 KUHPerdata ${ }^{11}$ sebagai landasan Fundamental dalam Pranata Keperdataan telah tercederai oleh hadirnya Pasal 178 UU K-PKPU tersebut. Hal demikian tentunya dapat merugikan kreditur dalam mendapatkan hak pembayaran apabila dilakukan Perdamaian setelah Penjatuhan Insolvensi tersebut. $^{12}$

Guna menghadapi permasalahan berkaitan dengan eksistensi Insolvensi tersebut, Peneliti akan melakukan kajian hukum melalui teori-teori yang relevan untuk merumuskan suatu rekomendasi apakah Insolvensi sebagaimana yang dimaksud dalam Pasal 178 ayat (1) tersebut telah sesuai dengan Persperktif Kepailitan pada umumnya yang patut untuk dipertahankan, atau patut untuk di lakukan perbaikan demi tercapainya keadilan, kemanfaatan dan kepastian hukum bagi Debitur maupun Kreditur.

Dalam Perspektif Umum di jelaskan bahwa tingkat solvabilitas seseorang atau suatu badan hukum (legal entity) ditentukan semata - mata dari kesanggupan debitur untuk membayar seluruh utang (is able to pay all of its debts) yang sudah jatuh tempo dan dapat ditagih. Menurut Michael Quintan, keadaan Insolven di Australia tidak semata - mata didentikkan berdasarkan balance sheet untuk melihat apakah ada surplus aset atas seluruh utang perseroan, tapi semata - mata di ukur dari keadaan cash flow yang ada.

"Insolvency is not ussualy determined merely by looking at the balance sheet of a copany and determaning whether there is a surplus of asssets over liabilities. Rather the emphasis is on cash flow. Of course companies may experience both types of insolvency simultaneously"13

\footnotetext{
${ }^{11}$ Pasal 1858 KUHPerdata

${ }^{12}$ Alesia Ranney-Marinelli, Overview of Chapter 15 Ancillary Other Cross-Border Cases, American Bankruptcy Law Journal, Volume 82, No. 5, Winter 2008, h. 271-272.

${ }^{13}$ Ibid.
} 
Untuk menilai keadaan finansial atau tingkat solvabilitas seorang debitur atau suatu legal entity,ada beberapa pendekatan Ilmu ekonomi yang lazim digunakan sebagai berikut: ${ }^{14}$

1. Insolven berdasarkan Cash Flow Test.

Dalam praktik peradilan di negara civil law, pendekatan klasik yang digunakan untuk mendekteksi keadaan insolven adalah berdasarkan cash flow test. Berdasarkan cash flow test, orang atau badan hukum dianggap telah insolven ketika dia tidak mampu membayar utangnya yang sudah jatuh tempo. Dari pendekatan cash flow test debitur dinilai telah insolven berdasarkan kondisi tidak adanya ketersediaan dana segar atau dana liquid yang demiliki debitur untuk membayar utang yang sudah jatuh tempo. Debitur yang telah berhenti membayar utang dikarenkaan ketiadaan uang tunai (cash) dinilai telah insolven.

2. Insolven berdasarkan Balance Sheet Test.

Dibandingkan dengan pendekatan cash flow test, pendekatan Balance Sheet Test dinilai lebih akurat menilai solvabilitas debitur yang tidak membayar utang karena ketiadaan persediaan uang tunai. Pendekatan Balance Sheet Test tidak memfokuskan penilaian solvabilitas debitur dari fakta telah tidak membayar utangnya yang yelah jatuh tempo atau dari ketiadaan ketersediaan dana liqid atau uang tunai yang dapat segera digunakan untuk membayar utang yang sudah jatuh tempo.

Pendekatan Balance Sheet Test berfokus pada perbandingan antara aset yang dimiliki debitur dengan besarnya kewajiban yang harus dipenuhi. Debitur yang tidak membayar utang dianggap insolven jika seluruh kewajiban untuk membayar (termasuk membayar biaya likuidasi) lebih besar jumlahnya dibanding sengan seluruh assetnya. Dalam kondisi yang demikian, debitur diperkirakan tidak akan dapat memenuhi kewajibannya untuk membayar seluruh utangnya yang sudah jatuh tempo maupun yang belum jatuh tempo dikemudian hari.

3. Insolven berdasarkan Going Concern Value.

Keadaan going concern atau kelangsungan usaha suatu badan hukum sebagai hasil opini dari seorang auditor. Dengan adanya going concern, suatu usaha dianggap akan mampu mempertahankan kegiatan usahanya dalam jangka waktu panjang tidak akan di likuidasi. Opini going concern yang diberikan oleh seseorang akuntan publik mengindikasikan perusahaan masih dapat meneruskan kelangsungan usahanya di masa yang akan datang, paling tidak untuk setahun ke depan.

Mechael C Dennis, menyebutkan 9 (sembilan) kondisi yang dapat dijadikan acuan bagi para Akuntan untuk tidak memberikan opini going concern. Kondisi - kondisi tersebut adalah sebagai berikut:

- Arus uang kas minus (negative cash flow).

- Mengalami kerugian secara terus menerus (significant net loss).

- Menurunnya penjualan dan permintaan secara signifikan (a serious decline in sales and in demand).

- Tidak dapat membayar utang kepada Kreditur separatis (default on dects owe secured creditors).

- Telah melanggar kesepakatan perjanjian pinjaman (loan covenant violation).

${ }^{14}$ Elyta Ras Ginting, 2019, Hukum Kepailitan, Sinar Grafika, Jakarta Timur, hlm 117 
- Adanya kewajiban yang belum jatuh tempo yang harus dilaksanakan pembayarannya (sizeable contingent liabilities).

- Terjadi pengembalian Produk secara massal (Major products recalls).

- Perusahaan mendapat sanksi pajak (taxs liens placed on the business).

- Perusahaan sedang di gugat secara hukum atas pelanggaran hak personal dari seseoranh yang di lakukan oleh perusahaan (law suits filed against the company in particular personal injury suit).

Bagaimana opini going concern dapat dijadikan acuan untuk mengukur tingkat solvabilitas suatu perusahaan secara gamblang dikemukakan oleh Darminto Hartono yang menyebutkan sebagai going concern value yaitu kedaan ekonomi dan keuangan perusahaan dalam keadaan beroperasi. ${ }^{15}$ Untuk menilai apakah suatu perusahaan yang mengalami kesulitan finansial masih berstatus going concern, Darminto menggunakan pendekatan Analytical Hierarchy Process dari rasio keuangan debitur. Adapun resiko keuangan debitur yang dijadikan sebagai peniliaan dalah liquiditas, solvabilitas, profitabilitas dan leverage perusahaan. Keempat rasio keuangan debitur tersebut masing - masing memberikan gambaran keadaan perusahaan sebagai berikut:

- Rasio likuditas memberikan informasi mengenai kemampuan perusahaan untuk memenuhi kewajiban jangka pendek yang dimiliki perusahaan.

- Solvabilitas mengukur kemampuan perusahaan untuk memenuhi kewajiban keuangan jangka panjang.

- Rasio Profitabilitas digunakan untuk mengukur kinerja perusahaan dalam menghasilkan keuntungan dari sumber daya yang dimiliki.

- Rasion leverage menjadi indikator dari resiko yang mungkin akan ditempuh oleh perusahaan dalam rangka menghasilkan keuntungan. ${ }^{16}$

Selain berfungsi untuk mengukur solvabilitas usaha debitur, rasio-rasio keuangan debitur tersebut, menurut Darminto dapat digunakan untuk menentukan prosedur uang ideal ditempuh manakala debitur mengajukan permohonan penundaan pembayaran utang (suspension of payment). Apakah cara yang ditempuh dengan memberi penundaan utang tetap dengan melakukan reorganisasi utang, atau dengan melikuidasi harta debitur (pailit). ${ }^{17}$

Untuk mengetahui sejauh mana kemampuan perusahaan debitur dapat memenuhi kewajiban keuangannya dilakukan dengan rasio leverage, Menurut Rudywan dan Badera, rasio leverage diukur dengan menggunakan rasio debt to total asset. Rasio leverage yang tinggi dapat berdampak buruk bagi kondisi keuangan perusahaan. Semakin tinggi rasio leverage, semakin menunjukkan kinerja keuangan perusahaan yang buruk dan dapat menimbulkan ketidakpastian mengenai kelangsungan hidup perusahaan. ${ }^{18}$

Berdasarkan uraian - uraian diatas, jelas bahwa dari sudut pandang pendekatan Ilmu ekonomi, peneliti menemukan keadaan Insolvensi tidak semata - mata diukur dari Perbandingan Aktiva dan Pasiva Debitur akan tetapi juga dapat diprediksi dari prospek kelangsungan usaha (going concern value) debitur.

15 Darminto Hartono, Economic Analysis of Law Atas Putusan PKPU Tetap, Penerbit Lembaga Studi Hukum dan ekonomi, Universitas Indonesia -Fakultas Hukum, Jakarta, 2009.hlm. 32

${ }^{16}$ Darminto,op.cit.,hlm 78-79

${ }^{17}$ Loc.cit.,hlm.80 dan 89

18 www.ojs.unud.ac.id, Arry Pratama Rudyawan, I Dewa Nyoman Badera, “Opini Audit Going Concern : Kajian Berdasarkan Modul Prediksi Kebangkrutan Pertumbuhan Perusahaan, Leverage dan Reputasi Auditor" di Akses tanggal 11 Juli 2018" 
Apabila melihat pranata kepailitan yang ada di Indonesia maka konsideran dari pembuatan UU K-PKPU, pada prinsipnya berlandaskan asas - asas sebagai berikut:

1. Asas Keseimbangan

2. Asas Kelangsungan Usaha.

3. Asas Keadilan

4. Asas Integrasi

Berdasarkan dari asas - asas yang di kemukakan diatas, maka menurut hemat peneliti, konsep kelangsungan usaha (Going Concern Value) dinilai lebih tepat menjadi konsideren UU K-PKPU yang ada di Indonesia. Hal ini dapat dilihat pada rumusan asas point ke 2 (dua) yang menerangkan di dalam UU K- PKPU terdapat ketentuan yang memungkinkan perusahaan debitor yang prospektif tetap dilangsungkan.

Untuk memahami apa yang dimaksud oleh UU K-PKPU sebagai kelangsungan usaha, kita harus meninjau ketentuan Pasal 104, Pasal 179 ayat (1) jo Pasal 180, Pasal 181, dan Pasal 183 UU K-PKPU yang mengatur mengenai kewenangan kurator untuk meneruskan usaha debitur meskipun telah dinyatakan pailit dan hak para kreditur untuk memutuskan usaha debitur pailit tetap dilanjutkan beroperasi meskipun harta pailit telah dalam keadaan insolvensi. Dengan kata lain, kelangsungan usaha debitur yang telah pailit dan harta pailit telah insolven diputuskan berdasarkan kesepakatan Para Kreditur Konkuren. ${ }^{19}$

Akan tetapi, sepintas lalu Peneliti menemukan suatu sikap mendua yang di tunjukkan oleh UU K-PKPU dalam menentukan keadaan Insolvensi. Disatu sisi, Pasal 2 ayat (1) UU K-PKPU mengatur syarat - syarat untuk dapat dinyatakan pailit mengindikasikan adanya keadaan Insolvensi berdasarkan pendekatan cash flow test yaitu Debitur yang memiliki dua atau lebih kreditur, tidak membayar lunas sedikitnya satu dari utangnya yang sudah jatuh tempo dan dapat ditagih. Redaksi kalimat tidak membayar lunas sedikitnya satu dari utangnya yang sudah jatuh tempo dan dapat ditagih mengindikasikan debitur tengah mengalami kesulitan liquiditas secara temporer. Padahal seperti yang peneliti uraian sebelumnya UU KPKPU secara inplisit mengandung asas kelangsungan usaha (Going Concern Value).

Sebagaimana yang menjadi Rumusan Masalah dalam Penelitian ini, peneliti menemukan formulasi yang dapat dijadikan instrumen untuk seseorang dan/atau badan hukum Lokal maupun Asing dapat dinyatakan Insolvensi berdasarkan Pasal 178 ayat (1) Undang - undang Nomor 37 Tahun 2004 yang berbunyi:

"Jika dalam rapat pencocokan piutang tidak ditawarkan rencana perdamaian, rencana perdamaian yang ditawarkan tidak diterima, atau pengesahan perdamaian ditolak berdasarkan putusan yang telah memperoleh kekuatan hukum tetap, demi hukum harta pailit berada dalam keadaan insolvensi”.

Menurut Peneliti, Keadaan Insolvensi yang dijabarkan dalam Pasal 178 ayat (1) UU K-PKPU tersebut diatas tidak merujuk pada keadaan Insolvensi berdasarkan pendekatan cash flow test, maupun balance sheet test atau konsep going concern value. Istilah keadaan tidak mampu membayar atau insolvensi yang di uraian dalam pasal tersebut juga tidak memiliki kaitannya dengan penilaian rasio keuangan debitur seperti likuiditas (liqidaty), solvabilitas (solvability), profitabilitas (profitability) dan leverage.

${ }^{19}$ Pasal 180 ayat 1 UU K-PKPU 
Keadaan Insolvensi menurut UU K-PKPU tidak dikaitkan dengan pendekatan rasio - rasio ekonomi maupun rasio pendekatan perspektif rezim Kepailitan pada umumnya, akan tetapi semata - mata ditentukan berdasarkan ada tidaknya kesepakatan perdamaian antara Debitur dan Kreditur pada saat "Penundaan Kewajiban Pembayaran Utang Sementara" (PKPUS). Untuk menghindari dari keadaan Insolvensi tersebut debitur harus mengajukan Proposal Perdamaian kepada para Krediturnya.

Namun demikian, kemampuan debitur mengusulkan proposal perdamaian (composition plan) tidak menjamin $100 \%$ bahwa debitur akan terlepas dari keadaan Insolvensi, Sukses tidaknya skema perdamaian yang diusulkan berada sepenuhnya ditangan para kreditur Konkuren, dan kalaupun Kreditur menyetujuinya, Pengadilan Niaga dapat mengintervensi perdamaian tersebut dengan cara tidak memberi pengesahan (homologasi) pada kesepakatan perdamaian tersebut.

Setelah harta pailit insolvensi, maka harta pailit akan dibereskan seluruhnya tanpa bantuan debitur, kecuali jika para kreditur menyepakati usaha debitur tetap berstatus going concern atau dilanjutkan beroperasi. Jika usaha debitur berstatus going concern, pemberesan atau likuidasi hanya dapat dilakukan terhadap harta pailit yang tidak digunakan untuk menyokong kelangsungan usaha debitur. Menurut J.B Huizink dalam hukum kepailitan titik perubahan ke tahap eksekutorial adalah pada saat terjadinya insolvensi:

"Harta Pailit berada dalam keadaan insolvensi berarti bahwa demi hukum utang - utang sipailit telah bersifat pasti dan bahwa utang - utang itu tidak dibayar. Ini berakibat bahwa kepailitan beralih ke tahap eksekutorial: barangbarang milik debitur di jual dan hasilnya dibagi diantara Kreditur”, 20

Dengan demikian, keadaan Insolvensi demi hukum memberi titel eksekutorial pada sita umum atas harta pailit, karena pada saat itu Kurator telah dapat melakukan penjualan secara umum (lelang) atas harta pailit tanpa izin dan bantuan debitur.

Apabila bertitik tolak terhadap Keadaan Insolvensi yang dialamatkan kepada PENAGA TIMUR (M) SDN BHD, Peneliti yang notabennya selaku Kuasa Hukum Para Kreditur dalam Perkara tersebut tidak menemukan suatu pendekatan cash flow test, maupun balance sheet test atau konsep going concern value dan juga tidak memiliki kaitannya dengan penilaian rasio keuangan debitur seperti likuiditas (liqidaty), solvabilitas (solvability), profitabilitas (profitability) dan leverage seperti yang berlaku dalam Perspektif Rezim Kepailitan pada umumnya.

Menurut Peneliti, hal tersebut tentunya tidak hanya merugikan kepentingan Debitur semata selaku Badan Hukum Asing yang beroperasi di wilayah Indonesia, melainkan juga kepentingan dari Para Kreditur itu sendiri, dimana konsekuensi dari Insolvensinya PENAGA TIMUR (M) SDN BHD tersebut telah mewajibkan Kurator yang diangkat pengadilan untuk segera melakukan pemberesan pemberesan terhadap harta milik debitur (boedel pailit), padahal secara nyata harta - harta PENAGA TIMUR (M) SDN BHD tersebut berada di Negara Malaysia yang notabennya di luar Yurisdiksi Negara Republik Indonesia yang sampai saat ini Kreditur tidak bisa menerima hak - haknya selaku Para pencari Keadilan. Artinya UU K-PKPU yang notabennya adalah suatu perundang - undangan yang menjamin kepastian hukum dan perlindungan hukum yang bersandarkan kepada kebenaran

${ }^{20}$ Huizink,J.B, Insolventie, Penerjemah: Pusat Studi Hukum dan ekonomi Fakultas Hukum Universitas Indonesia, 2004,Jakarta hlm, 7 dan 68 
dan keadilan maka dalam hal ini, menurut peneliti UU K-PKPU tersebut tidak mampu menjamin pelaksanakan sesuai dengan penerapannya yang seharusnya.

Selain dari apa yang telah di jelaskan diatas, Peneliti juga menemukan sebuah fakta dimana PENAGA TIMUR (M) SDN BHD selaku Debitur tidak memiliki kesempatan lagi untuk mengajukan Perdamaian terhadap Para Kreditur dikarenakan kondisinya yang telah mengalami Insolvensi. Walaupun pada hakikatnya PENAGA TIMUR (M) SDN BHD selaku Debitur menganggap dirinya mampu untuk membayar seluruh utang - utangnya terhadap Kreditur namun hal tersebut secara hukum tidaklah dapat dibenarkan, hal ini telah sesuai dengan pendapat SEVENT RONI SIANTURI,S.H selaku Kurator dalam Perkara tersebut yang berhasil Peneliti wawancarai, yang mengatakan:

“Kesempatan PENAGA TIMUR (M) SDN BHD untuk mengajukan Perdamaian sudah tertutup dikarenakan keadaan Insolvensi, tidak ada lagi perdamaian setelah ini, terkait mengapa Kurator tidak menjalankan Usaha Debitur sebagaimana yang diatur dalam Pasal 179 ayat (1) UU K-PKPU, itu dikarenakan PENAGA TIMUR (M) SDN BHD berada di Negara Malaysia yang tidak mungkin dijalani oleh Kurator, selain dari pada itu Kurator hanya tunduk dan taat atas UU K-PKPU, walaupun PENAGA TIMUR (M) SDN BHD menyatakan dirinya mampu tapi pada saat PKPU $S$ tidak mengajukan Proposal Perdamaian ia harus dianggap insolvensi."

Selain dari dari pada hal tersebut SEVENT RONI SIANTURI,S.H menambahkan:

"di dalam UU K-PKPU tidak ada mengatur tentang apakah dia mampu atau tidak, Kurator juga tidak diwajibkan untuk menilai melalui pendekatan cash flow test, maupun balance sheet test atau konsep going concern value, intinya apabila tidak mengajukan Proposal Perdamaian dia harus Pailit dengan kedudukan harta Insolvensi”.

Dari hasil wawancara yang dilakukan antara Peneliti dan Kurator diatas, maka sangat jelas titik tolak dari Insolvensinya debitur salah satunya adalah bersumber dari debitur yang tidak mengajukan Proposal Perdamaian terhadap Kreditur walaupun tanpa melalui test Insolvensi berupa: pendekatan cash flow test, maupun balance sheet test atau konsep going concern value.

Padahal apabila UU K-PKPU tersebut lebih mengkaji lagi tentang Perspektif Rezim kepailitan pada umumnya, menurut Peneliti yang lebih adil dan bijaksana adalah apabila Debitur Asing yang tidak mengajukan Proposal Perdamaian dalam PKPUS selama 45 Hari maka seyogyanya Debitur Asing tersebut dapat nyatakan Pailit tanpa dijatuhkan keadaan insolvensi, hal ini dikarenakan dalam konteks kepailitan dalam UU K-PKPU menyatakan bahwa apabila debitur dinyatakan pailit maka masih terbuka pintu lebar untuk melaksanakan perdamaian, berbeda dengan keadaan Insolvensi yang suka tidak suka mau tidak mau Kurator harus melaksanakan pemberesan terhadap seluruh harta - harta debitur Pailit. Hal demikian tentunya dapat merugikan para kreditur yang semestinya dapat menerima pembayaran dari Debitur untuk melaksanakan perdamaian namun harus dikunci oleh penerapan Pasal 178 ayat (1) UU K-PKPU tersebut.

2. Peranan Kurator dalam memenuhi hak - hak Para Kreditur terhadap bodle pailit yang berada di Luar Negeri

Kurator melaksanakan tugas - tugasnya untuk melakukan pengurusan dan pemberesan harta pailit sejak adanya pernyataan pailit, debitor demi hukum kehilangan haknya untuk menguasai dan mengurus kekayaannya yang dimasukkan 
dalam kepailitan. Hal ini telah sesuai dengan pasal 16 ayat (1) UU Kepailitan dan PKPU yang menyatakan:

"Kurator berwenang melaksanakan tugas pengurusan dan/atau pemberesan atas harta pailit sejak tanggal putusan pailit diucapkan meskipun terhadap putusan tersebut diajukan kasasi atau peninjauan kembali”.

Pasal 69 ayat (2) huruf a UU K-PKPU telah meletakkan fondasi dari pelaksanaan tugas kurator yaitu kurator memiliki otoritas sepenuhnya untuk mengurus harta pailit dan dalam melakukan tugasnyam kurator tidak diharuskan memperoleh persetujuan dari atau menyampaikan pemberitahuan terlebih dahulu kepada debitur atau salah satu organ debitur, meskipun dalam keadaan di luar kepailitan persetujuan atau pemberitahuan demikian dipersyaratkan. ${ }^{21}$ Tindakan kurator tetap sah dan mengikat debitur pailit meskipun dilakukan tanpa izin debitur atau salah satu organ debitur. Bahkan meskipun ternyata kepailitan atas debitur dicabut atau dibatalkan, tindakan kurator tetap sah dan mengikat, Pengertian dari perbuatan kurator tetap sah dan mengikat debitur diuraikan dalam penjelasan Pasal 16 ayat (2) UU K-PKPU sebagai berikut:

"Yang dimaksud dengan tetap sah dan mengikat adalah bahwa perbuatan kurator tidak dapat digugat di pengadilan manapun”

Agar tidak keliru menafsirkan pengertian dari kalimat tidak dapat digugat di pengadilan manapun redaksi penjelasan Pasal 16 ayat (2) UU K-PKPU tersebut tentunya harus dibaca berbarengan dengan ketentuan pasal 72 UU Kepailitan dan PKPU yang menegaskan bahwa:

“Kurator bertanggung jawab terhadap kesalahan atau kelalaiannya dalam melaksanakan tugas pengurusan dan/atau pemberesan yang menyebabkan kerugian terhadap harta pailit”.

Dengan demikian, menurut Peneliti kurator tidak memiliki Immunitas dari segala tuntutan hukum sehubungan dengan tugas pengurusan dan pemberesan harta pailit yang dilakukannya. Sebagai Subjek Hukum yang dapat dimintakan pertanggungjawabannya di hadapan hukum yang berlaku, kurator tetap dapat dituntut untuk mempertanggung jawabkan pelaksanaan dari kewenangannya apabila perbuatan kurator telah merugikan harta pailit.

Secara umum, peranan kurator dalam melakukan pengurusan dan pemberesan harta pailit pada pokoknya meliputi 8 (delapan) tahapan yaitu:

a. Mempublikasikan putusan pailit.

b. Menghimpun dan menginventarisir harta debitur pailit dan mengamankan harta pailit,

c. Pendaftaran tagihan kreditur dan pencocokan utang.

d. Mengelola dan meneruskan perusahaan debitur pailit yang masih memiliki prospek untuk meningkatkan nilai harta pailit atau going concern.

e. Penjualan pra-insolven:

Sebelum harta pailit insolvensi, kurator atas izin hakim pengawas dapat melakukan penjualan harta pailit apabila biaya pemeliharaan benda tersebut membebani harta pailit atau diperlukan untuk menambah biaya operasional dari usaha debitur yang dilanjutkan beroperasi.

f. Menjual seluruh harta pailit apabila harta pailit dinyatakan insolvensi dan kelangsungan usaha debitur pailit dihentikan atau tidak diusulkan oleh Kurator dan Para Kreditur konkuren beroperasi.

${ }^{21}$ Pasal 69 ayat (2) huruf a UU Nomor 37 Tahun 2003 
g. Membayar para kreditur dari hasil penjualan harta pailit sesuai dengan jenis dan sifat piutang sebagaimana telah ditetapkan dalam daftar pembagian yang telah disahkan oleh hakim pengawas dan telah memiliki kekuatan hukum tetap.

h. Mengembalikan dana jika terdapat efisiensi harta pailit terhadap kewajibannya. ${ }^{22}$

Terkait kedudukan Harta Pailit (boedel pailit), Pasal 21 UU K-PKPU telah mengatur "bahwa kepailitan meliputi seluruh kekayaan debitur pada saat putusan pernyataan pailit diucapkan serta segala sesuatu yang diperoleh selama kepailitan". Dari rumusan pasal 21 UU PKPU tersebut maka dapat ditafsirkan jika prinsip Kepailitan di Indonesia mengandung Asas Universal namun disatu sisi Indonesia juga merupakan prinsip teritorial yang tidak akan mengakui putusan kepailitan negara asing. Sehingga dapat dipahami bahwa bisa jadi hal ini yang menyebabkan putusan kepailitan Indonesia tidak diakui oleh negara - negara asing sebab di Negara Indonesia tidak secara serta merta mengakui putusan - putusan asing, jadi secara singkat apabila ditinjau dari UU Nomor 37 Tahun 2004 menganut prinsip Universal dalam arti putusan pailit pengadilan niaga di Indonesia seharusnya dapat diberlakukan tidak hanya di Indonesia melainkan juga di luar Wilayah Indonesia, sebaliknya Indonesia juga menganut Prinsip Teritorial terhadap putusan pailit pengadilan asing yang berdampak pada aset debitur pailit yang berada di wilayah Indonesia, sehingga putusan pailit Pengadilan Asing tidak dapat dilaksanakan di Wilayah Republik Indonesia.

Sehubungan dengan hal tersebut diatas, apabila dikaitkan dengan fokus penelitian ini yang bertitik tolak terhadap Peranan Kurator dalam perkara Nomor: 11/Pdt.Sus-PKPU/2018/PN Niaga Mdn tertanggal 11 Oktober 2018 perihal Insolvensinya Debitur Penaga Timur (M) SDN.BHD atas Permohonan PKPU yang diajukan oleh Para Kreditur PT. Wijaya Artha Shiping (PT.WAS) dan PT. Ujung Medini Lestari (PT.UML) yang terbukti memiliki tagihan sebesar Rp. 12.991.106.500,- (dua belas milyar sembilan ratus Sembilan puluh satu juta seratus enam ribu lima ratus rupiah) terhadap Debitur Penaga Timur (M) SDN.BHD, maka secara hukum Kurator yang diangkat oleh pengadilan dimanahkan untuk melakukan pemberesan terhadap boedel pailit milik Penaga Timur guna memenuhi hak - hak Para Kreditur yang telah di akui berdasarkan Putusan yang berkekuatan Hukum tetap.

Sebagaimana yang telah peneliti uraikan sebelumnya, Kurator berwenang untuk menjual seluruh harta pailit apabila harta pailit dinyatakan insolvensi dan kelangsungan usaha debitur pailit dihentikan atau tidak diusulkan oleh Kurator dan Para Kreditur konkuren beroperasi serta membayar para kreditur dari hasil penjualan harta pailit sesuai dengan jenis dan sifat piutang sebagaimana telah ditetapkan dalam daftar pembagian yang telah disahkan oleh hakim pengawas dan telah memiliki kekuatan hukum tetap. Akan tetapi dalam Perkara Nomor: 11/Pdt.Sus-PKPU/2018/PN Niaga Mdn sebagai fokus penelitian ini, Kurator yang diangkat Pengadilan sangat kesulitan untuk melaksanakan pemberesan pemberesan terhadap harta - harta (boedel pailit) milik Debitur Penaga Timur (M) SDN BHD yang terletak di Negara Malaysia, hal ini sesuai dengan Hasil Wawancara yang dilakukan antara Peneliti terhadap Kurator SEVENT RONI SIANTURI,S.H yang menerangkan jika:

"Kurator sangat kesulitan melakukan pemberesan terhadap boedel pailit milik Debitur Penaga Timur (M) SDN BHD, hal ini terjadi lantaran seluruh aset -

${ }^{22}$ Elyta Ras Ginting, Loc cit hlm 138. 
asetnya berada di Negara Malaysia sementara Putusan Indonesia tidak secara serta merta di akui oleh Mahkamah Malaysia oleh karena antara Indonesia dengan malaysia belum melakukan kerjasama bilateral dibidang kepailitan (cross border insolvency)"

Namun SEVENT RONI SIANTURI,S.H selaku Kurator menjelaskan secara rinci terhadap usahanya guna memenuhi hak - hak Kreditur atas boedel pailit milik Debitur asing Penaga Timur (M) SDN.BHD, yaitu:

1. Pada hari Kamis tanggal 25 Oktober 2018, Kurator telah berhasil mengamankan 1 (satu) Unit Kapal MV.Tuah 2,GT.168 milik Debitur Pailit Penaga Timur (M) SDN.BHD yang masuk di perairan Indonesia (tidak termasuk dokumen - dokumen kapal) hal ini telah dituangkan dalam Berita Acara Serah Terima Nomor: PL.201/01/01/KSOP.TBK-2018 dari Kantor Kesyahbandaran dan Otoritas Pelabuhan Kelas II Tg Balai Karimun.

2. Kurator telah mendesak KSOP Karimun untuk segera mencari Dokumen Kapal MV Tuah 2 tersebut yang saat itu di kuasai oleh PT. LINTAS LAUTAN INDONESIA (PT.LLI) selaku Agen Kapal Penaga Timur (M) SDN BHD, oleh karenanya KSOP Karimun telah mengeluarkan:

1) Surat Penyerahan Dokumen MV. TUAH 2 tertanggal 05 Oktober 2018;

2) Permintaan Penyerahan Dokumen MV. TUAH 2 tertanggal 10 Oktober 2018 ;

3) Permintaan Penyerahan Dokumen MV. TUAH 2 tertanggal 11 Oktober 2018;

4) Peringatan Nomor: UM.003/18/6/KSOP.TBK-2018 tertanggal 24 Oktober 2018;

Namun sampai saat ini Dokumen Kapal MV.Tuah 2 tidak kunjung diserahkan oleh PT.LLI kepada KSOP Karimun dengan alasan Dokumen Kapal berada di Melaysia yang di kuasai langsung oleh Penaga Timur (M) SDN.BHD.

3. Melaksanakan Penetapan Hakim Pengawas Nomor 06/HP/11/Pdt.SusPKPU/2018/PN Niaga Mdn tertanggal 11 Oktober 2018 yang pada pokoknya memerintahkan Kementerian Perhubungan cq Direktorat Jenderal Perhubungan Laut untuk mencabut izin operasi dan trayek kapal milik atau kapal yang di operasikan oleh Penaga Timur (M) SDN BHD (dalam pailit) dan mencabut hal - hal lain yang berhubungan dengan kegiatan Penaga Timur (M) SDN BHD, karena sudah dinyatakan pailit sehingga tidak dapat melakukan tindakan dan kewenangan hukum lagi.

4. Mengajukan bantuan penyelesaian Kepailitan Lintas batas Negara terhadap Kedutaan Besar Republik Indonesia di Kuala Lumpur-Malaysia dan telah mendapatkan respon sesuai dengan Surat yang di keluarkan oleh KBRI di Kuala Lumpur Nomor 2974/WN/10/2018/12 tanggal 29 Oktober 2018, akan tetapi sampai dengan saat ini tidak bisa dilaksanakan karena malaysia memiliki keadaulatan tersendiri.

5. Mengajukan Surat terhadap Unit Pemerintahan Ekonomi Negeri (UPEN) Johor dengan nomor 21/KKP-SRS/PT (M) SDN BHD-PAILIT/X/2018 tertanggal 24 Oktober dan UPEN Johor membalasa Surat Kurator tersebut pada tanggal 28 November 2018 yang isinya akan mencoba mendiskusikan permasalahan tersebut terhadap Debitur Pailit Penaga Timur (M) SDN.BHD.

6. Kurator kembali mengajukan Surat Nomor: 57/KKP-SRS/PT(M) SDN BHDPAILIT/I/2019 tertanggal 08 Januari 2019 ke Kedutaan Besar Republik Indonesia aq Atase Perhubungan di Kuala Lumpur perihal pelaksanaan Penetapan hakim Pengawas pada Pengadilan Negeri Medan. 
7. Mengajukan Surat kepada PT.LLI selaku Agen Debitur Pailit Penaga Timur (M) SDN. BHD di Indonesia pada tanggal 26 Oktober 2018, perihal himbauan penyerahan laporan kegiatan dan pendapatan penjualan tiket kapal-kapal yang dioperasikan Penaga Timur (M) SDN BHD.

8. Membuat Laporan Kepolisian berdasarkan Penetapan Hakim Pengawas Perkara a quo Nomor: 9/HP/11/Pdt.Sus-PKPU/2018/PN.Niaga.Mdn tertanggal 14 November 2018 tentang Dugaan Tindak Pidana Penggelapan sebagaimana yang diatur dalam Pasal 372 KUHPidana yang di duga di lakukan oleh PT.LINTAS LAUTAN INDONESIA dimana pada saat Penaga Timur (M) SDN BHD Pailit, PT.LLI selaku agen masih mengageni kapal-kapal milik Penaga namun tidak menyerahkannya kepada Kurator, oleh karena itu setelah di lakukan audit oleh Kurator, kurator mengalami kerugian sebesar Rp. 2.000.000.000,- (dua milyar rupiah) yang seharusnya uang tersebut masuk kedalam boedel Pailit.

Selain dari pada tindakan - tindakan yang dilakukan oleh Kurator diatas, Hakim Pengawas dalam Perkara a quo juga telah mengeluarkan Penetapan demi memperlancar proses pemberesan atas harta pailit (boedel pailit) Penaga Timur (M) SDN BHD diantaranya :

- Penetapan Nomor 6/HP/11/Pdt.Sus-PKPU/2018/PN.Niaga.Mdn. tertanggal 11 Oktober 2018 yang berbunyi:

1. Memerintahkan agar kepala Kantor Kesyahbandaran dan Otoritas Pelabuhan Kelas II Tanjung Balai Karimun untuk menahan keberangkatan Kapal MV Tuah 2 keluar dari Pelabuhan Tanjung Balai Karimun tanpa izin Kurator yang ditunjuk Pengadilan Niaga Medan;

2. Memerintahkan kepada Kepala Kantor Kesyahbandaran dan Otoritas Pelabuha Kelas II Tanjung Balai Karimun agar menyerahkan Dokumen Dokumen Kapal MV Tuah 2 izin kepada Kurator dalam berita acara yang sah;

3. Memerintahkan kepada Kepala Kantor Kesyahbandaran dan Otoritas Pelabuha Kelas II Tanjung Balai Karimun untuk menahan setiap kepemilikan kapal - kapal dari Penaga Timur (M) SDN BHD (dalam pailit) yang telah menjadi harta pailit;

4. Memerintahkan kementerian Perhubungan cq Direktorat Jenderal Perhubungan Laut untuk mencabut izin operasi dan trayek Kapal Milik atau Kapal yang di operasikan oleh Penaga Timur (M) SDN BHD (dalam pailit), memberhentikan Jalur Pelayaran Pelabuhan Tanjung Balai Karimun - Terminal Antara Bangsa Kukup Malaysia di bawah Pengurusan Penaga Timur (M) SDN BHD (dalam pailit), dan mencabut hal - hal lain yang berhubungan dengan kegiatan Penaga Timur (M) SDN BHD, karena sudah dinyatakan Pailit sehingga tidak dapat melakukan tindakan dan kewenangan hukum lagi;

5. Memerintahkan kepada Kepala Kantor Kesyahbandaran dan Otoritas Pelabuha Kelas II Tanjung Balai Karimun untuk berkoordinasi dengan Kurator yang telah ditunjuk oleh Pengadilan Niaga pada Pengadilan Negeri Medan.

- Penetapan Nomor 9/HP/11/Pdt.Sus-PKPU/2018/PN.Niaga.Mdn. tertanggal 14 November 2018 yang berbunyi:

1. Memerintahkan kepada Kantor Kesyahbandaran dan Otoritas Pelabuhan Kelas II Tanjung Balai Karimun untuk mengeluarkan Surat Persetujuan Berlayar terhadap Kapal MV Tuah 2 untuk diberangkatkan menuju Pulau 
Batam dalam rangka pengamanan, pengurusan dan pemberesan harta pailit.

2. Memerintahkan kepada Kantor Kesyahbandaran dan Otoritas Pelabuha Kelas II Tanjung Balai Karimun untuk menurunkan (sign off) Crew Kapal MV Tuah 2 dan mengambalikan crewnya kepada Perusahaan yang mengeluarkan perjanjian kerja melalui agen yang di tunjuk di Tanjung Balai Karimun.

3. Memerintahkan kepada Kantor Syahbandaran dan Otoritas Pelabuhan Kelas II Tanjung Balai Karimun untuk memutuskan kegiatan Debitur Pailit Penaga Timur (M) SDN BHD (dalam pailit) termasuk tidak melayani MV. Tuah 1, MV.Putra Maju 07, MV Trans JB dan menutup seluruh kegiatan keagenan dan pihak - pihak yang menggunakan nama dan fasilitas Debitur Pailit Penaga Timur (M) SDN BHD (dalam Pailit) di Wilayah Republik Indonesia;

4. Memerintahkan kepada Kantor Kesyahbandaran dan Otoritas Pelabuhan Kelas II Tanjung Balai Karimun baik secara sendiri-sendiri maupun bersama-bersama Kurator dan Instansi Terkait untuk melakukan Investigasi terhadap Keagenan ataupun pihak-pihak yang menggunakan Fasilitas Debitor Pailit namun tidak melaporkan hasil usahanya kepada Kurator;

5. Memerintahkan kepada Kantor Kesyahbandaran dan Otoritas Pelabuhan kelas II Tanjung Balai Karimun beserta Kurator Penaga Timur (M) SDN BHD (dalam pailit) untuk melakukan tindakan hukum, melaporkan kepada Kepolisian Republik Indonesia dan Instansi terkait terhadap keagenan dan pihak - pihak yang menghalangi pelaksanaan Putusan dan Penetapan dari Pengadilan Niaga pada Pengadilan Negeri Medan.

Dari penetapan - penetapan yang dikeluarkan oleh Hakim Pengawas dan tindakan - tindakan Kurator dalam melaksanakan pemberesan, menurut hemat peneliti, kesulitan kurator dalam melaksanakan Peranannya selaku Kurator dalam memenuhi hak - hak Para Kreditur terhadap boedle pailit milik Penaga Timur (M) SDN BHD dikarenakan boedel Pailit tersebut berada di luar Yurisdiksi Negara Republik Indonesia. Serta dalam keadaannya, Indonesia tidak memiliki hubungan kerjasama bilateral dengan Negara Malaysia yang sejatinya apabila hal tersebut dilakukan maka tentu memudahkan Kurator dalam melaksanakan pemberesan demi mengisi boedel pailit untuk memenuhi hak - hak Para Kreditur.

Sehubungan dengan hal tersebut diatas, maka di berbagai negara telah nya menggunakan alternatif -alternatif untuk melakukan konvensi, perjanjian bilateral, dan multilateral guna mengatur mengenai mekanisme kepailitan lintas batas sebagaimana yang akan di jelaskan dibawah ini:

1. Konvensi yang diikuti oleh Negara Ciprus Negara Belanda dan Negara Portugal yang di lakukan pada tahun 1971 yang pada pokoknya mengatur tentang pelaksanan putusan - putusan dalam Perkara Perdata dan Dagang.

2. Komisi Hukum Perdagangan (UNCITRAL) yang dibentuk pada tahun 1997 oleh Perserikatan Bangsa - Bangsa (PBB) yang pada pokoknya untuk pelaksanaaan Putusan - putusan kepailitan yang tergabung dalam Anggota PBB, namun konvensi belum di gratifikasi oleh Indonesia.

3. Perjanjian bilateral tentang kepailitan lintas negara antar Negara Malaysia dan Negara Singapura dimana pada pokoknya masing - masing 
negara secara serta merta mengakui kedudukan putusan - putusan yang di keluarkan oleh negara - negara tersebut.

4. Perjanjian Multirateal yang dibuat oleh negara - negara Uni Eropa yang disebut sebagai The European Union Convention on Insolvency Proceedings (2000) . ${ }^{23}$

Dari alternatif - alternatif yang di jelaskan diatas, menurut Hemat Peneliti, salah satu alasan fundamental mengapa Indonesia belum bisa mengadopsi dan masuk dalam konvensi -konvensi diatas tidak terlepas dari Sistem Kepailitan Indonesia yang sangat berbeda dengan Perspektif Umum Kepailitan pada umumnya sebagaimana yang dijelaskan Peneliti dalam Pembahasan sebelumnya. Dan akibatnya, Peranan kurator dalam melakukan Pemberesan di luar negeri bagaikan Singa yang tak memiliki taring, disatu sisi Undang - undang mewajibkan Kurator untuk melaksanakan pemberesan terhadap seluruh Boedel Pailit namun disisi lain undang - undang tersebut mengalami inkonsistensi dalam penerapannya. Padahal pengaturan tentang ketentuan badan hukum asing untuk diajukan Kepailitan di Indonesia telah diatur tegas dalam Pasal 3 ayat 4 UU K-PKPU. Namun disisi lain Inkonsistensi UU K-PKPU tersebut dapat juga kita lihat dari minimnya pengaturan ketentuan - ketentuan Hukum Internasional berkaitan dengan Pemberesan Boedel Pailit dan/atau Cross Border Insolvensy dalam ketentuan perundang - undangan UU K-PKPU.

UU K-PKPU bagian kesepuluh tentang Ketentuan - Ketentuan Hukum Internasional hanya memuat pasal - pasal, yaitu:

- Pasal 212:

"Kreditor yang setelah putusan pernyataan pailit diucapkan, mengambil pelunasan seluruh atau sebagian piutangnya dari benda yang termasuk harta pailit yang terletak di luar wilayah Negara Republik Indonesia, yang tidak diperikatkan kepadanya dengan hak untuk didahulukan wajib mengganti kepada harta pailit segala apa yang diperolehnya."

- Pasal 213

1) "Kreditor yang memindahkan seluruh atau sebagian piutangnya terhadap Debitor Pailit kepada pihak ketiga, dengan maksud supaya pihak ketiga mengambil pelunasan secara didahulukan daripada orang lain atas seluruh atau sebagian piutangnya dari benda yang termasuk harta pailit yang terletak di luar wilayah Negara Republik Indonesia, wajib mengganti kepada harta pailit apa yang diperolehnya”.

2) "Kecuali apabila dibuktikan sebaliknya maka setiap pemindahan piutang wajib dianggap telah dilakukan sesuai dengan ketentuan sebagaimana dimaksud pada ayat (1), apabila pemindahan tersebut dilakukan oleh Kreditor dan Kreditor tersebut mengetahui bahwa pernyataan pailit sudah atau akan diajukan”.

- Pasal 214

1) "Setiap orang yang memindahkan seluruh atau sebagian piutang atau utangnya kepada pihak ketiga, yang karena itu mendapat kesempatan untuk melakukan perjumpaan utang di luar wilayah Negara Republik Indonesia yang tidak diperbolehkan oleh Undang-Undang ini, wajib mengganti kepada harta pailit”.

${ }^{23}$ Dr. Susanti Adi Nugroho,S.H.,M.H, 2018, Hukum Kepailitan di Indonesia, Prenadamedia Group, Jakarta, hlm. 427 
2) “Ketentuan Pasal 213 ayat (2) berlaku juga terhadap hal sebagaimana dimaksud pada ayat (1)”.

Sehubungan dengan inkonsistensi -nya UU Nomor 37 Tahun 2004, baik dari segi Sistem Kepailitan Indonesia yang sangat berbeda dengan Perspektif Umum Kepailitan yang mengakibatkan tidak diakuinya Sistem Kepailitan Indonesia di Luar negeri maupun dari minimnya pengaturan ketentuan - ketentuan Hukum Internasional berkaitan dengan Pemberesan Boedel Pailit dan/atau Cross Border Insolvensy yang menyebabkan terhambatnya peranan Kurator dalam memenuhi hak - hak para Kreditur terhadap bodle pailit yang berada di Luar Negeri, telah nyata merugikan hak - hak para kreditur selaku para Pencari keadilan dan memiliki hak mendapatkan perlindungan hukum sebagaimana yang terkandung dalam Pasal 28D ayat 1 UUD 1945 sebagai landasan filosofis yang berbunyi:

"Setiap orang berhak atas pengakuan, jaminan, perlindungan, dan kepastian hukum yang adil serta perlakuan yang sama di hadapan hukum".

Keadaan tersebut tentunya berbenturan dengan Teori Perlindungan hukum dalam penelitian ini, dimana Menurut Philiphus M. Hadjon, negara Indonesia sebagai negara hukum berdasarkan Pancasila haruslah memberikan perlindungan hukum terhadap warga negara sesuai dengan Pancasila. ${ }^{24}$ Sehingga Peranan hukum dalam perwujudannya terhadap masyarakat adalah dengan memberikan perlindungan kepada masyarakat yang kepentingannya terganggu. Jika terjadi konflik atau sengketa di dalam kehidupan masyarakat, maka harus segera diselesaikan menurut hukum yang berlaku, sehingga dapat mencegah perilaku main hakim sendiri. Perlindungan kepentingan masyarakat dengan menciptakan tatanan masyarakat yang tertib, sehingga terwujud kehidupan yang seimbang adalah merupakan tujuan pokok dari hukum itu sendiri. Dalam hal ini Peneliti menyimpulkan Perlindungan Hukum yang represif sebagaimana yang dicita citakan bersama tidak mengakomodir hak - hak Para Kreditur dalam Perkara Kepailitan Peradilan Niaga Nomor Putusan Nomor 11/Pdt.SusPKPU/2018/PN.Niaga Mdn.

Selain dari pada itu, peneliti juga menemukan sebuah fakta bahwa inkonsistensi -nya UU Nomor 37 Tahun 2004 sebagaimana yang di jelaskan sebelumnya, telah merengkut hak - hak Para Kreditur sebagai Warga Negara Indonesia untuk memperoleh keadilan, oleh karenanya Pemerintah dalam Arti Luas kiranya dapat menempatkan kembali prinsip keadilan dalam setiap dasar kebijakan pemerintah. Dalam hal ini, keadilan yang dimaksud adalah apa yang tercantum pada sila ke-5 Pancasila, yang berbunyi : "Keadilan sosial bagi seluruh rakyat Indonesia". Selanjutnya pemaknaan keadilan sosial telah sesuai dengan Pembukaan UndangUndang Dasar 1945, alinea keempat yang berbunyi sebagai berikut:

“...... melindungi segenap bangsa Indonesia an seluruh tumpah darah Indonesia, memajukan kesejahteraan umum, mencerdaskan kehidupan bangsa, dan ikut melaksanakan ketertiban dunia yang berdasarkan kemerdekaan, perdamaian abadi dan keadilan sosial dengan berdasarkan kepada : Ketuhanan Yang Maha Esa, Kemanusiaan yang adil dan beradab, Persatuan Indonesia, Kerakyatan yang dipimpin oleh hikmat kebijaksaaan dalam permusyawaratan dan perwaklan dan Keadilan sosial bagi seluruh rakyat Indonesia".

${ }^{24}$ Philipus M. Hadjon, Perlindungan Hukum bagi Rakyat Indonesia(Sebuah Studi tentang prinsipprinsipnya, Penanganannya oleh Pengadilan dalam Lingkungan Peradilan Umum), Surabaya, PT Bina Ilmu, 1987, hlm. 84. 
3. Langkah - langkah yang dapat digunakan untuk memberi kepastian hukum bagi Para Kreditur atas boedle pailit yang berada di Luar Negeri

Pada hakikatnya Pranata Kepailitan dibentuk sebagai wadah terhadap Kreditur untuk melakukan penagihan utang - piutang nya terhadap debitur yang tidak melunasi utangnya,

Dari sujud sejarah hukum, undang - undang kepailitan pada mulanya bertujuan untuk melindungi para kreditur dengan memberikan jalan yang jelas dan pasti untuk menyelesaikan utang yang tidak dapat terbayar, yang pengurusan dan pemberesannya dilakukan oleh Kurator dibawah pengawasan hakim pengawas sebagaimana yang diatur dalam UU K-PKPU.

Berdasarkan perspektif normatif, pengertian kepailitan dapat dilihat di dalam Ketentuan Pasal 1 angka 1 UU K-PKPU yang menyebutkan bahwa:

"Kepailitan adalah sita umum atas semua kekayaan Debitor Pailit yang pengurusan dan pemberesannya dilakukan oleh Kurator di bawah pengawasan Hakim Pengawas sebagaimana diatur dalam Undang-Undang ini.”

Selanjutnya akibat kepailitan yang dialami oleh Debitur dapat kita tinjau dalam Pasal 21 UU K-PKPU yang menyatakan "Kepailitan meliputi seluruh kekayaan Debitor pada saat putusan pernyataan pailit diucapkan serta segala sesuatu yang diperoleh selama kepailitan."dapat diartikan bahwa putusan pailit yang di ucapkan di Indonesia meliputi Aset debitur paiit baik dalam maupun di luar wilayah hukum republik Indonesia.

Kedua ketentuan tersebut diatas, memang tidak menjelaskan secara konkret perihal penormaan prinsip universal dalam hukum kepailitan, namun rumusan frasa "semua/seluruh kekayaan debitur" dapat dikontruksikan secara meluas sehingga meliputi seluruh kekayaan debitur baik dimanapun kekayaan tersebut terletak.

Berdasarkan pemaparan diatas, menurut peneliti bahwa walaupun prinsip universal tidak disebutkan sebagai jantung dalam peraturan perundang - undangan kepailitan di Indonesia, namun dengan adanya sifat Universal dalam hukum kebendaan sebagai jaminan pelunasan utang piutang sebagaimana yang dimaksud dalam Pasal 1 angka 1 jo Pasal 21 UU K-PKPU, maka prinsip Universal tidak hanya bersifat mengatur dan menjelaskan namun eksistensinya sendiri telah dinormakan dalam peraturan perundang - undangan tentang kepailitan, sehingga penormaan prinsip universal pada dasarnya dikehendaki untuk tidak hanya memiliki keberlakuan secara filosofis namun juga secara yuridis.

Sebagaimana yang dijelaskan dalam bab - bab sebelumnya, fokus penelitian ini bertitik tolak terhadap Perlindungan Kreditur atas Insolvensinya Debitur Asing Penaga Timur (M) SDN.BHD sesuai dengan Putusan Nomor: 11/Pdt.SusPKPU/2018/PN Niaga Mdn tertanggal 11 Oktober 2018, dimana sampai dengan peneliti yang notabennya selaku Kuasa Hukum Para Kreditur melaksanakan penelitian ini, Hak - Hak Para Kreditur belum kunjung di penuhi oleh Kurator yang bertugas untuk melaksanakan penjualan harta - harta milik Penaga Timur (M) SDN BHD.

Walaupun secara formil Pasal 1 angka 1 jo Pasal 21 UU K-PKPU secara tegas menyatakan bahwa seluruh harta kekayaan debitur merupakan Aset Pailit, namun dalam kenyataannya hal tersebut hanyalah bersifat tekstualitas yang tidak memiliki daya paksa dalam pelaksanaannya. Dan jika bertitik tolak terhadap UU K-PKPU bagian kesepuluh tentang Ketentuan - Ketentuan Hukum Internasional dari Pasal 212, Pasal 213 ayat (1) dan (2), Pasal 214 ayat (1) dan (2) maka secara komprehensif Peneliti tidak menemukan satu aturan pun yang mengatur mengenai langkah - 
langkah yang dapat digunakan untuk memberi kepastian hukum bagi para kreditur atas boedle pailit yang berada di luar negeri.

Menurut Peneliti, ketentuan - ketentuan Internasional yang tercantum dalam UU K-PKPU tersebut, hanya menitik beratkan terhadap perbuatan - perbuatan Kreditur untuk mengambil piutangnya dari Debitur ataupun Pihak ketiga yang bersifat sukarela (volountir) dan/atau bersifat kesepakatan saja, tanpa mengatur dengan lugas mengenai upaya - upaya dalam melakukan pemberesan terhadap Harta pailit yang berada di Luar Wilayah Republik Indonesia, dalam hal ini Peneliti berpendirian bahwa telah terjadi kekosongan hukum terhadap pengatuean Cross Borderr Insolvency.

Sehubungan terjadinya kekosongan hukum dalam penerapan Pasal 1 angka 1 jo Pasal 21 UU K-PKPU terhadap Harta Pailit yang berada di Luar Indonesia tersebut, dan bersandarkan kepada semangat aksioma Para Penegak Hukum yakni Fiat justitia ruat coeleum (hukum harus tetap ditegakkan, biarpun langit runtuh), maka menurut peneliti pemenuhan hak - hak Para Kreditur haruslah di jalankan dengan bersungguh - sungguh sebagai bentuk pertanggung jawaban atas Instrumen UU K- PKPU yang telah mengatur:

- Pasal 3 ayat (4) UU KPKPU yang menyebutkan bahwa "dalam hal debitur tidak berkedudukan di wilayah negara Republik Indonesia tetapi menjalankan profesi atau usahanya di wilayah negara Republik Indonesia, Pengadilan yang berwenang memutuskan adalah Pengadilan yang daerah hukumnya meliputi tempat kedudukan atau kantor pusat Debitor menjalankan profesi atau usahanya di wilayah negara Republik Indonesia”;

- Pasal 1 angka 1 UU K-PKPU yang menyebutkan bahwa: "Kepailitan adalah sita umum atas semua kekayaan Debitor Pailit yang pengurusan dan pemberesannya dilakukan oleh Kurator di bawah pengawasan Hakim Pengawas sebagaimana diatur dalam Undang-Undang ini.”

- Pasal 21 UU K-PKPU yang menyebutkan bahwa "Kepailitan meliputi seluruh kekayaan Debitor pada saat putusan pernyataan pailit diucapkan serta segala sesuatu yang diperoleh selama kepailitan.”

- Pasal 178 ayat (1) UU K-PKPU yang menyebutkan bahwa "Jika dalam rapat pencocokan piutang tidak ditawarkan rencana perdamaian, rencana perdamaian yang ditawarkan tidak diterima, atau pengesahan perdamaian ditolak berdasarkan putusan yang telah memperoleh kekuatan hukum tetap, demi hukum harta pailit berada dalam keadaan insolvensi”

Berangkat dari uraian - uraian di atas, menurut peneliti perlu kiranya diberikan langkah - langkah yang dapat digunakan untuk memberi kepastian hukum bagi Para Kreditur atas Boedel Pailit Penaga Timur (M) SDN BHD di Malaysia adalah:

1. Kurator harus bertanggung jawab menjalankan pemberesan sebagaimana yang di amanahkan dalam UU K-PKPU dengan cara mengajukan Tuntutan terhadap Penaga Timur (M) SDN.BHD di negara Malaysia, hal ini sesuai tanggung jawab kurator yang diatur dalam pasal 16 ayat (1) UU Kepailitan dan PKPU yang selaras dengan Pasal 21 UU K-PKPU tentang kedudukan boedel pailit yang bersifat universal. Oleh karena adanya kewilayahan suatu negara, berdasarkan prinsip universal tersebut maka Kurator harus mengajukan tuntutannya dengan menggunakan mekanisme negara Malaysia. Kurator juga harus secara maksimal melaksanakan tugasnya berdasarkan ketentuan UU Kepailitan dan PKPU terhadap boedel pailit Penaga Timur (M) SDN BHD yang berada di wilayah Indonesia, mengingat terdapat fakta bahwa Kapal milik perusahaan tersebut 
telah disita di pelabuhan Kabupaten Karimun, dengan cara menjual kapal tersebut atau setidaknya meminta perusahaan Penaga Timur untuk mengganti senilai likuidasi dari kapal dimaksud.

2. Pemerintah harus segera membahas terkait Kepailitan Lintas Batas (Cross Border Insolvensi) terkhusus dalam Perkara ini Peneliti berharap Pemerintah segera mengajukan Perjanjian Bilateral mengenai Kepailitan terhadap Pemerintahan Negara Malaysia, sebagai bentuk perlindungan dan kepastian hukum bagi Para Kreditur.

Langkah - langkah yang dijelaskan Peneliti di atas, sejatinya sesuai dengan apa yang menjadi hakikat dalam Teori Perlindungan hukum yang dikemukakan Philiphus M. Hadjon yaitu: negara Indonesia sebagai negara hukum berdasarkan Pancasila haruslah memberikan perlindungan hukum terhadap warga negara sesuai dengan Pancasila. ${ }^{25}$ Sehingga Peranan hukum dalam perwujudannya terhadap masyarakat adalah dengan memberikan perlindungan kepada masyarakat yang kepentingannya terganggu. Jika terjadi konflik atau sengketa di dalam kehidupan masyarakat, maka harus segera diselesaikan menurut hukum yang berlaku, sehingga dapat mencegah perilaku main hakim sendiri. Perlindungan kepentingan masyarakat dengan menciptakan tatanan masyarakat yang tertib, sehingga terwujud kehidupan yang seimbang adalah merupakan tujuan pokok dari hukum itu sendiri. Dalam hal ini Peneliti menyimpulkan Perlindungan Hukum yang represif sebagaimana yang dicita - citakan bersama tidak mengakomodir hak - hak Para Kreditur dalam Perkara Kepailitan Peradilan Niaga Nomor Putusan Nomor 11/Pdt.Sus-PKPU/2018/PN.Niaga Mdn.

\section{E. Kesimpulan.}

1. Perspektif rezim hukum kepailitan dalam memandang Debitur Asing yang Insolvensi berdasarkan Undang - Undang Nomor 37 Tahun 2004 tentang Kepailitan dan Penundaan Kewajiban Pembayaran Utang.

Keadaan Insolvensi yang dijabarkan dalam Pasal 178 ayat (1) Undang Undang Nomor 37 Tahun 2004 tidak merujuk pada keadaan Insolvensi berdasarkan pendekatan cash flow test, maupun balance sheet test atau konsep going concern value. Istilah keadaan tidak mampu membayar atau insolvensi yang di uraian dalam pasal tersebut juga tidak memiliki kaitannya dengan penilaian rasio keuangan debitur seperti likuiditas (liqidaty), solvabilitas (solvability), profitabilitas (profitability) dan leverage.

Keadaan Insolvensi menurut UU K-PKPU tidak dikaitkan dengan pendekatan rasio - rasio ekonomi maupun rasio pendekatan perspektif rezim Kepailitan pada umumnya, akan tetapi semata - mata ditentukan berdasarkan ada tidaknya kesepakatan perdamaian antara Debitur dan Kreditur pada saat Penundaan Kewajiban Pembayaran Utang Sementara (PKPUS). Untuk menghindari dari keadaan Insolvensi tersebut debitur harus mengajukan Proposal Perdamaian kepada para Krediturnya.

${ }^{25}$ Philipus M. Hadjon, Perlindungan Hukum bagi Rakyat Indonesia(Sebuah Studi tentang prinsipprinsipnya, Penanganannya oleh Pengadilan dalam Lingkungan Peradilan Umum), Surabaya, PT Bina Ilmu, 1987, hlm. 84. 
Khususnya berkenaan dengan Insolvensinya Penaga Timur (M) SDN BHD Perusahaan Asing Asal Negara Malaysia, Peneliti tidak menemukan suatu pendekatan cash flow test, maupun balance sheet test atau konsep going concern value dan juga tidak memiliki kaitannya dengan penilaian rasio keuangan debitur seperti likuiditas (liqidaty), solvabilitas (solvability), profitabilitas (profitability) dan leverage seperti yang berlaku dalam Perspektif Rezim Kepailitan pada umumnya.

\section{Peranan Kurator dalam memenuhi hak - hak Para Kreditur terhadap bodle pailit yang berada di Luar Negeri.}

Dari beberapa konvensi, perjanjian bilateral, dan multilateral yang dilakukan oleh Negara-negara yang di jelaskan salah satu alasan fundamental mengapa Indonesia belum bisa mengadopsi dan masuk dalam konvensi -konvensi diatas tidak terlepas dari Sistem Kepailitan Indonesia yang sangat berbeda dengan Perspektif Umum Kepailitan pada umumnya sebagaimana yang dijelaskan Peneliti dalam Pembahasan sebelumnya. Akibat perbedaan Sistem Kepailitan tersebut mengakibatkan urungnya negara Asing negara Asing mengakui Putusan Kepailitan di Indonesia.

Peranan kurator dalam melakukan Pemberesan di luar negeri bagaikan Singa yang tak memiliki taring, disatu sisi Undang - undang mewajibkan Kurator untuk melaksanakan pemberesan terhadap seluruh Boedel Pailit namun disisi lain undang - undang tersebut mengalami inkonsistensi dalam penerapannya. Padahal pengaturan tentang ketentuan badan hukum asing untuk diajukan Kepailitan di Indonesia telah diatur tegas dalam Pasal 3 ayat 4 UU K-PKPU. Namun disisi lain Inkonsistensi UU K-PKPU tersebut dapat juga kita lihat dari minimnya pengaturan ketentuan - ketentuan Hukum Internasional berkaitan dengan Pemberesan Boedel Pailit dan/atau Cross Border Insolvensy dalam ketentuan perundang - undangan UU K-PKPU.

Sehubungan dengan inkonsistensi -nya UU Nomor 37 Tahun 2004, baik dari segi Sistem Kepailitan Indonesia yang sangat berbeda dengan Perspektif Umum Kepailitan yang mengakibatkan tidak diakuinya Sistem Kepailitan Indonesia di Luar negeri maupun dari minimnya pengaturan ketentuan - ketentuan Hukum Internasional berkaitan dengan Pemberesan Boedel Pailit dan/atau Cross Border Insolvensy yang menyebabkan terhambatnya peranan Kurator dalam memenuhi hak - hak para Kreditur terhadap bodle pailit yang berada di Luar Negeri, telah nyata merugikan hak - hak para kreditur selaku para Pencari keadilan dan memiliki hak untuk mendapatkan perlindungan hukum sebagaimana yang terkandung dalam "Pasal 28D ayat 1 UUD 1945" sebagai landasan filosofis yang berbunyi:

"Setiap orang berhak atas pengakuan, jaminan, perlindungan, dan kepastian hukum yang adil serta perlakuan yang sama di hadapan hukum”.

\section{Langkah - langkah yang dapat digunakan untuk memberi kepastian} hukum bagi Para Kreditur atas boedle pailit yang berada di Luar Negeri.

Secara formil Pasal 1 angka 1 jo Pasal 21 UU K-PKPU dengan tegas menyatakan bahwa seluruh harta kekayaan debitur merupakan Aset Pailit, namun dalam kenyataannya hal tersebut hanyalah bersifat tekstualitas yang tidak memiliki daya paksa dalam pelaksanaannya. Dan jika bertitik tolak terhadap UU K-PKPU bagian kesepuluh tentang Ketentuan - Ketentuan Hukum Internasional dari "Pasal 212, Pasal 213 ayat (1) dan (2), Pasal 214 ayat (1) dan (2)" maka secara komprehensif Peneliti tidak menemukan satu aturan pun yang mengatur mengenai langkah - 
langkah yang dapat digunakan untuk memberi kepastian hukum bagi para kreditur atas boedle pailit yang berada di luar negeri.

Ketentuan - ketentuan Internasional yang tercantum dalam UU K-PKPU tersebut, hanya menitik beratkan terhadap perbuatan - perbuatan Kreditur untuk mengambil piutangnya dari Debitur ataupun Pihak ketiga yang bersifat sukarela (volountir) dan/atau bersifat kesepakatan saja, tanpa mengatur dengan tegas mengenai upaya - upaya dalam melakukan pemberesan terhadap Harta pailit yang berada di Luar Wilayah Republik Indonesia, dalam hal ini telah terjadi kekosongan hukum.

Sehubungan tidak adanya pengaturan yang mengatur mengenai Pemberesan Harta Pailit di Luar Wilayah Indonesia, maka perlu kiranya diberikan langkah langkah yang dapat digunakan untuk memberi kepastian hukum bagi Para Kreditur atas Boedel Pailit Penaga Timur (M) SDN BHD di Malaysia antara lain:

1. Kurator harus bertanggung jawab untuk menjalankan pemberesan sebagaimana yang di amanahkan dalam UU K-PKPU dengan cara mengajukan Tuntutan terhadap Penaga Timur (M) SDN.BHD di negara Malaysia, hal ini sesuai tanggung jawab kurator yang diatur dalam pasal 16 ayat (1) UU Kepailitan dan PKPU yang selaras dengan Pasal 21 UU K-PKPU tentang kedudukan boedel pailit yang bersifat universal.

2. Pemerintah harus segera membahas pengaturan - pengaturan mengenai "Kepailitan Lintas Batas (Cross Border Insolvensi)” terkhusus dalam Perkara ini Peneliti berharap Pemerintah segera mengajukan Perjanjian Bilateral mengenai Kepailitan terhadap Pemerintahan Negara Malaysia, sebagai bentuk perlindungan dan kepastian hukum bagi Para Kreditur.

\section{DAFTAR PUSTAKA}

\section{Buku}

Bayu Seto Hardjowahono, Dasar - Dasar Hukum Perdata Internasional Buku Kesatu, Bandung: PT Citra Aditya Bakti, 2006.

Darminto Hartono, Economic Analysis of Law Atas Putusan PKPU Tetap, Jakarta: Penerbit Lembaga Studi Hukum dan ekonomi, Universitas Indonesia -Fakultas Hukum, 2009.

Elyta Ras Ginting, Hukum Kepailitan- Teori Kepailitan, Jakarta: Sinar Grafika, 2018.

Huizink,J.B, Insolventie, Jakarta, Penerjemah: Pusat Studi Hukum dan ekonomi Fakultas Hukum Universitas Indonesia, 2004.

Mukti Fajar ND, Yulianto Achmad, Dualisme Penelitian Hukum Normatif \& Empiris, Yogyakarta: Pustaka Pelajar, 2010.

Sudargo Gautama, Hukum Perdata Internasional Indonesia Buku Kesatu, Bandung: PT Alumni, 2008.

Susanti Adi Nugroho, Hukum Kepailitan di Indonesia, Jakarta: Prenadamedia Group, 2018. 


\section{Artikel}

Alesia Ranney-Marinelli, Overview of Chapter 15 Ancillary Other CrossBorder Cases, American Bankruptcy, Law Journal, Volume 82: Winter, 2008.

Sunaryati Hartono, Manfaat Ketentuan - Ketentuan Internasional dalam Penyelesaian Harta Pailit, Makalah Seminar Sosialisasi Rancangan Undang - Undang Tentang Kepailitan: Badan Pembinaan Hukum Nasional - Departemen Kehakiman bekerja sama dengan elips Project, 1999.

Warren J Keegan, Global Marketing Management, Sevent Edition, United State: Prentice Hall, 2002.

\section{Internet}

www.ojs.unud.ac.id, Arry Pratama Rudyawan, I Dewa Nyoman Badera, "Opini Audit Going Concern : Kajian Berdasarkan Modul Prediksi

Kebangkrutan Pertumbuhan Perusahaan, Leverage dan Reputasi Auditor" di Akses tanggal 11 Juli 2018"

\section{Peraturan Perundang -Undangan}

Undang-Undang Dasar Republik Indonesia 1945.

Kitab Undang - Undang Hukum Perdata.

Kitab Undang - Undang Hukum Dagang.

Indonesia. Undang - Undang Nomor 37 Tahun 2004 tentang Kepailitan

dan Penundaan Kewajiban Pembayaran Utang. 